УДК

94(497.11)"1941/1945"(049.2)

001.3:050.486(497.11)(049.2)

DOI https://doi.org/10.31212/tokovi.2020.3.jan.193-207

Научна критика и полемика

Примљена: 10. 6. 2020.

Прихваћена: 1. 10. 2020.

Zoran JANJETOVIĆ

Institute for Recent History of Serbia, Belgrade

kokanzokan@yahoo.com

\title{
On Lists, Indexes, and Quality: Is there a Connection?
}

ABSTRACT: Starting from the argument-based critique of one of
the papers indexed in the Web of Science Core Collection, the
article examines if there is a connection between quality of works,
journals in which they are published, lists in which these journals
feature and indices that list these articles, advertising authors
who often do not deserve it. The paper deals with the untoward
consequences of such a short-sighted practice and argues in favor
of a constant revision of the lists and indices supported by the
Ministry of Education, Science, and Technological Development
of the Republic of Serbia, thus increasing the relevance of the
lists and indexes applied as yardsticks of academic achievement.
KEY woRDS: Journals, Lists, Indexes, Methodology, Forced Labor

A scurry for publishing in journals that are on some of the famed lists that bring the author coveted points, has started in our historiography during the last couple of years. This mania (that has already been summarized by Western wits as publish or perish) was not invented in Serbia, but was imported alongside the lists of recommended journals and prestigious indices. Like so many things we take over from the "whole wide world," these were sometimes taken mechanically and without due consideration to what extent these lists and indices are adequate to our needs and possibilities. This concerns above all journals from the humanities and indices that list the published papers in the humanities. There is no need to explain that the lists drawn by commercial Western publishers need not automatically be relevant for our scientific community, or at least for its humanist section. Therefore, supplementing, 
changing, and constantly revising these lists is a serious task that should be approached with a great deal of caution. Advising our researchers to publish in journals incompetent for topics of their research, can cause manifold damages. Matching otherwise good journals with topics their editors do not know much about and therefore cannot chose right referees to, ensure a quality control of the submitted articles, can damage the reputation of these journals on one hand, and bring points and publicity to authors who maybe do not deserve them by putting them on indices that help establish scholars' reputations. This in turn can lead to them being favored over others who may be better when it comes to applying for project funding, grants, research, or teaching jobs etc. At the same time, such unsound articles and studies contaminate the academic space with unreliable results that are later on taken for granted and "copied and pasted" by less knowledgeable authors who rely solely on the reputation of the journals, where the papers they quote had been published, or on the indices on which they had been listed. All this is clearly contrary to the intentions of those who make or apply lists and indices and certainly also to the intentions of the Ministry of Education, Science, and Technological Development of the Republic of Serbia.

The so-called "predatory" journals are another problem: they prey on scholars from their e-mail mailboxes, offering their "services" for a handful of dollars. Some scholars, less informed about the journals on the official lists of the Ministry, or those seeking an easy way to publish, might be tempted to accept their offers, misleading in turn, their readers into overrating the journal in which the article was published. As an illustration, we shall make a brief review of the article by Marija Obradović and Nada Novaković entitled: Milan Nedic's Quisling Regime and Forced Labor in Serbia from 1941 to 1944, which appeared in the E-Journal International and Comparative Labor Studies, VIII, 3, 2019, published by the ADAPT University Press. This article was chosen for two reasons. First, because it was indexed in the Web of Science Core Collection, which would imply that it not only possesses exceedingly high quality, but that it has been published in a journal acknowledged as very good. Second, this particular paper was chosen because it writes about a topic that this author has dealt with many times and knows very well. We felt it would be neither fair nor wise to choose an article from a field about which we know little or nothing, in order to substantiate the views we seek to promote.

Although the journal in which it appeared is not on the list of the Serbian Ministry of Education, Science, and Technological Development, 
the paper in question was indexed in the Web of Science Core Collection, so one would expect the journal in which it was published to be on the highest editorial and academic level. However, already a first glance at the article in question shows that it is not so. Namely, in the abstract of the above quoted article, in the passage entitled Purpose, it says: "The study aims to substantiate the approaches and principles of forming and regulation (sic) of a model of social and labor relations of Kazakhstan adequate to the modern conditions of economic development." The rest of the abstract deals with the same topic concerning conditions in Kazakhstan. As key words, the following are adduced: Social and Labor Relations, Kazakhstan, Model, Labor Market Institutions, Social Partners. ${ }^{1}$ Obviously, it is an editorial error, i.e. someone supplied the article by Marija Obradović and Nada Novaković with the wrong abstract. To be sure, these things happen sometimes, but it is hardly admissible in a journal that aspires to be among the leading ones. However, if such obvious slips happen to a journal, the ministry should re-examine the value of the results published in it. Although this particular journal is not on the ministry's list, the fact that the paper in question was indexed in the Web of Science Core Collection could establish an ambiguous connection with the ministry's intentions i.e. the article could mislead readers into believing that the journal in question is on the Ministry's list.

Even if we accept that mistakes like the ones mentioned above sometimes happen and are forgivable, it is much harder to accept the content of the article itself that indicates that the reviewers (who presumably have read the text and approved it for publication) do not know much about the subject of the article they had reviewed. In a much more substantial way this should disqualify such a journal as a source of articles to be indexed in the Web of Science Core Collection.

Let us now turn to the article itself. What is the problem with it? Briefly, the paper we have chosen for our spot-check contains a number of methodological errors, as well as factual mistakes that are due to its methodological shortcomings. The first methodological error is a visceral ideological slant inadmissible in a historiographical work aspiring to be scholarly. ${ }^{2}$ The authors prove their ideological bias already in the first

1 Marija Obradović, Nada Novaković, "Milan Nedic's Quisling Regime and Forced Labor in Serbia from 1941 to 1944" , E-Journal of International and Comparative Labour Studies 3/2019, 86.

2 Indeed, the authors give the first hint of this already in the wording of the title by using ideologically-laden term Quisling regime (without explaining the choice), instead of a more general and ideologically neutral, collaborationist regime (or gov- 
sentence: "Revisionist narratives are currently highly present in the historiography of Serbia." This is followed by the next claim that the main direction of that revisionism is aimed at denying the collaborationist nature of the movement of Draža Mihailović (i.e. the Chetniks) and the "quisling administration" of Milan Nedić. ${ }^{3}$ Since these are serious accusations, one would expect them to be reinforced by at least several titles in the footnotes. However, the authors do not offer a single one, ${ }^{4}$ whereas, for some reason, the reviewers and editors have chosen to take them at their word - which should not be the trait of top-notch academic journals. To make things worse, throughout the text, the authors put forward claims and data that are not substantiated by any archival document or historiographical title. This reduces to a high degree the scholarly credibility of the article since historiography is not literary story-telling where the author enjoys the implicit trust of the benevolent reader.

Mentioning in the introductory part the court trials aimed at rehabilitating the Chetniks and Draža Mihailović, the authors also mention the canonization of Bishop Nikolaj Velimirović, whom they accuse of having been the "founder of the political ideology of St. Sava nationalism, which was the basis for the fascist organization called Zbor, headed (sic) by Dimitrije Ljotić." Both claims are debatable. It is true that Nikolaj Velimirović used St. Sava to depict Serbian nationalism as the oldest in Europe, ${ }^{5}$ but he was neither the first, nor the only one to connect that particular saint with Serbian nationalism. ${ }^{6}$ Much more problematic is the claim that this Serbian nationalism was the basis of the "fascist organization, Zbor" Historians differ about whether Zbor was a fascist or just an extreme right-wing organization. ${ }^{7}$ What is certain is that although he was a nationalism-con-

ernment). However, this is within limits of the acceptable, since the choice of the title is rather a matter of taste.

3 Ibid.

$4 \quad$ To tell the truth, there are works that really seek to change the image of Draža Mihailović, the chetniks, Milan Nedić and other whom the historiography of the socialist era simply labeled as quislings, but as a rule these are memoirs and publicists works, while works with academic pretensions and at the same time "revisionist" tendencies (as the authors perceive them) are few.

5 Николај Велимировић, Национализам светог Саве, (Београд: Мала народна библиотека, 1994), 8.

6 Geert Van Dartel, "Nationalities and Religion in Yugoslavia", Yearbook of European Studies 5/1992, 5; Холм Зундхаусен, Историја Србије од 19. до 21. века, (Београд: Clio, 2008), 318.

7 For diverging opinions cf.: Branislav Gligorijević, „Osobenosti fašizma u Jugoslaviji dvadesetih godina“, Marksistička misao 3/1986, 35, 41; Branislav Gligorijević, „Politički pokreti i grupe s nacionalsocijalističkom ideologijom i njihova fuzija u Ljotiće- 
scious Serb, Dimitrije Ljotić was a Yugoslav nationalist. For that reason there were some Yugoslav-oriented Croats and Slovenes who were active in his movement. Ljotić turned to purely Serbian nationalism during the occupation of Serbia in World War II when it was forbidden to even mention Yugoslavia: at the end of the war he tacitly reverted to his Yugoslav convictions since the situation allowed it once again. ${ }^{8}$

The authors write further that the administration of Milan Nedic (whose name is always, for reasons unknown, misspelled as Nedic, ${ }^{9}$ although one would expect to find the correct spelling and grammar in the top-notch journal) ${ }^{10}$ was guilty of war crimes and 150.000 deaths. ${ }^{11}$ With such a statement the authors proved their aversion to objectivity and their penchant for ideological and unproven claims. Although the Nedić government did take part in war crimes, most of them were committed by the occupying forces and German troops, who played the key role in the

vom 'Zboru'“, Istorijski glasnik 4/1965, 35-83; Todor Kuljić, Fašizam. Socioliško-istorijska studija, (Beograd: Nolit, 1987²), 228-252; Жарко С. Јовановић, Неостварени ратни циљеви Драже Михаиловића у Србији 1941-1945, (Београд: Институт за новију историју Србије, 2001), 71; Василије Драгосављевић, „Идеолошки утицаји европског фашизма на ЈНП Збор (1934-1940)“, Историјска трибина младих сарадника, (Београд: ИНИС 2013), 93-108; Who Were the Fascists. Social Roots of European Fascism, eds Stein Ugelvik Larsen, Bernt Hagtvet, Jan Petter Myklebust, (Bergen, Oslo, Tromsø: Universitetsforlaget 1980); Stanley G. Payne, A History of Fascism 1914-1945, (London, New York: Rutledge 2003), 15, 186-190, 325. It should also be kept in mind that there is no generally accepted deffinition of fascism. (Cf. Comparative Fascist Studies. New Perspectives, ed. Constantin Iordachi, (London, New York: Taylor and Francis Ltd, 2010), VIII, 1; Payne, A History of Fascism, 461; Mikloš Lacko, „Fašizam u istočnoj i srednjoj Evropi. Prilog opštoj definiciji fašizma“, Marksistička misao 3/1986, 123)

8 On Ljotić cf. works by this author where extensive bibliography of writings, both favorable and unfavorable for Dimitrije Ljotić and the Zbor, are to be found: Zoran Janjetović, Collaboration and Fascism under the Nedić Regime, (Belgrade: Institut za noviju istoriju Srbije, 2018), 122-144; Zoran Janjetović, "Dimitrije Ljotić - ein antieuropäischer Europäer unter jugoslawischen Politkern" , Attraktionen und Irritationen. Europa und sein Südosten im langen 19. Jahrhundert, ed. Harald Heppner, (Berlin: Peter Lang 2019), 179-194; Zoran Janjetović, „Dimitrije Ljotić and World War II“, Istorija 20. veka 1/2018, 93-118. True enough, some of Ljotić's followers were primarilly Serbian nationalists (especially during WWII), but it is also true that some two hundred pro-Yugoslav Croats, certain number of Slovenes, Bosnians and others fought within his Serbian Volunteer Detachments.

9 Letters č, ć, đ, š are always missing in the main text, even though they do appear in the footnotes.

10 This goes for a text in any language, regardless of the country where a journal appears. The article we chose to examin contains quite a few linguistic mistakes, some of which are visible in the quotations we adduced. We chose just to mark them with "sic", without further comment.

11 Obradović, Novaković, "Milan Nedic’s Quisling Regime“, 86. 
oppression of occupied Serbia. ${ }^{12}$ As for the number of dead, the authors showed that they took it over from official data sanctified by the post-war Yugoslav authorities. Here too they showed the tendency either to take the easy way, or accept what appealed to them ideologically. As in several other places, the authors uncritically accept the official numbers reached by the State Commission for Establishing Crimes of the Occupiers and their Abettors and its branches in the then Yugoslav republics, disregarding the fact that these commissions were acting under the most unfavorable circumstances, working against the clock and not primarily with the aim of establishing the historical truth, but gathering data necessary for putting forward Yugoslavia's reparation claims (the higher, the better).$^{13}$ This by no means implies that the crimes on which the commissions collected data did not happen, but that the numbers of victims, ${ }^{14}$ and sometimes even the identity of the perpetrators were dubitable.

Apart from the ideological partisanship, the main methodological error of the authors lies in the fact that they did not use some of the most relevant works dealing with their subject matter. As a consequence, they mixed up facts, showed bias, and drew the wrong conclusions. Thus, in footnote 3 on page 87, the authors cite some really relevant works, but then they never quote them again. ${ }^{15}$ If they had really used them, the authors would have avoided a number of factual mistakes that will be mentioned below. In this context, as an inadmissible methodological slip, we

12 On the leading role of the German authorities and troops in repression cf.: Venceslav Glišić, Teror i zločini nacističke Nemačke u Srbiji 1941-1944, (Beograd: Rad, 1970); Ben Shepherd, Terror in the Balkans. German Armies and Partisan Warfare, (Harvard: Harvard University Press, 2012); Valter Manošek, Holokaust u Srbiji. Vojna okupaciona politika i uništavanje Jevreja 1941-1942, (Beograd: Službeni list, 2007).

13 Zoran Janjetović, "Devisen statt Entschädigung. Die Wiedergutsverhandlungen zwischen der Bundesrepublik und Jugoslawien", Die Grenzen der Wiedergutmachung. Die Entschädigung für NS-Verfolgte in West- und Osteuropa 1945-2000, eds Hans Günter Hockerts, Claudia Moisel, Tobias Winstel, (Göttingen: Wallstein Verlag, 2006), 633-644. Thus Yugoslavia proffered the number of 1.3 million dead, that was later on raised to 1.7 million by Tito himself. In fact, these were calculated demographic losses, and not actual war-related deaths. (Cf.. Vladimir Žerjavić, Population Loses in Yugoslavia 1941-1945, (Zagreb: Dom i svijet, 1997), 55)

14 Thus, paradoxically, the State Commission for Establishing Crimes of Occupiers and their Abettors found that during the whole wartime occupation 16.500 people had worked at Bor, whereas the documents from 1943 show that 20.000 worked at Bor during that year alone. (Cf. Zoran Janjetović, „U skladu sa nastalom potrebom “... Prinudni rad u okupiranoj Srbiji 1941-1944, (Beograd: Institut za noviju istoriju Srbije, 2012), 212-213)

15 Above all the following works: Živko Avramovski, Treći rajh i Borski rudnik, (Bor: Muzej rudarstva i metalurgije, 1975); Janjetović, „U skladu sa nastalom potrebom“. 
must mention the non-use of the book by Karl-Heinz Schlarp (that was not even mentioned), the major work on Serbia's economy in WWII. ${ }^{16} \mathrm{Al}-$ though Schlarp did not deal extensively with forced labor, the data he supplied on the work force, prices, wages, productivity, etc., explain the context in which "mandatory" (i.e. de facto forced) labor was performed. The authors quote only in one place the monograph by Dragan Aleksić on the same topic, in which the best pages were devoted precisely to the labor force. ${ }^{17}$ They also do not quote the article by the same author devoted exclusively to forced labor ${ }^{18}$ whereas they refer to another one only indirectly by mentioning the collection of papers where it was published ${ }^{19}-$ which is methodologically negligent, to say the least. On the other hand, the authors quote in 14 places the book by Milan Borković, Kontrarevolucija $\mathrm{u}$ Srbiji. ${ }^{20}$ This massive work, ${ }^{21}$ despite being encumbered by ideological ballast, retains its value, but it devotes only $2.5 \%$ of the whole text to economic matters - including forced labor. ${ }^{22}$ This hardly makes it so relevant as to be quoted 14 times in an article on forced labor. The situation is similar to the paper The Exploitation of Foreign Labor by Germany published by the International Labor Office in Montreal in $1945,{ }^{23}$ which was cited no less than seven times. When it comes to contemporary sources, it would have been methodologically much sounder (and therefore academically much more fruitful) to quote first-hand German and not second-hand foreign sources. One could cast doubt on the reliability of the information gathered in such a short time and sent across the Atlantic - but the authors never asked themselves that question. It would have been better if the authors had used at least some of the modern works on

16 Karl-Heinz Schlarp, Wirtschaft und Besatzung in Serbien 1941-1944. Ein Beitrag zur nationalsozialistischen Wirtschaftspolitik in Südosteuropa, (Stuttgart: Franz Steiner Verlag, 1986).

17 Драган Алексић, Привреда Србије у Другом светском рату, (Београд: Институт за новију историју Србије, 2002).

18 Dragan Aleksić, „Problem radne snage u industriji i rudarstvu Srbije u Drugom svetskom ratu“, Tokovi istorije 3-4/1997, 89-110.

19 It is the article by Dragan Aleksić, „Prinudni rad u Srbiji u Drugom svetskom ratu“, Logori, zatvori i prisilni rad u Hrvatskoj/Jugoslaviji 1941-1945, 1945-1951, ed. Vladimir Geiger, (Zagreb: Hrvatski institut za povijest, 2010), 132-149.

20 Milan Borković, Kontrarevolucija u Srbiji. Kvislinška uprava u Srbiji 1941-1944, I-II, (Beograd: Sloboda, 1979).

21 The work has 769 pages of main text in two volumes.

22 Cf. Zoran Janjetović, "The Exploatation of Economy and Manpower in the Territory of Yugoslavia during the Second World War. Historiographical Overview. Results and Pending Research“, Südost-Forschungen 77/2018, 259.

23 The Exploatation of Foreign Labour by Germany, (Montreal: International Labor Office, 1945). 
forced labor ${ }^{24}$ that offer a broader picture of the phenomenon based on World War II primary sources. It is difficult to discern if negligence, ideological bias, or both, are responsible for such extensive use of Borkovićs book and the above mentioned paper, with disregard for more relevant literature and better primary sources. In any case, their disregard for basic academic methodology leads to faulty results - which in turn sheds poor light on the authors, their work, and last but not least, the journal in which it was published, ${ }^{25}$ since its editors should have warned the authors of the shortcomings of their paper. Consequently, it also sheds poor light on the Web of Science Core Collection.

Having briefly pointed to the main methodological weaknesses of the article in question, we shall now turn to the factual errors caused by the disregard for professional methodology. ${ }^{26}$ Thus, the authors claim on page 90 that the Organization Todt ran the Bor mining complex. This claim is incorrect since the mine was owned by a consortium of German companies. ${ }^{27}$ The authors made an even bigger mistake by inventing the company with the name Todtbor (sic!). This came about because they utilized the already mentioned paper The Exploitation of Foreign Labor by Germa$n y$ - which is an excellent example of what results sloppy methodology brings. To make things worse, the authors contradict themselves claiming on page 102 that Bor and the major metallurgical installations were run by the Bor-Kupferbergwerk. This claim is also not completely true. In fact it was a company called Bor Kupferbergwerke und Hütten AG that was created in the spring of 1944 after long negotiations between several interested companies. ${ }^{28}$ If the authors had really used the works cited in their bibliography, such an oversight would not have crept in.

On page 91 the authors claim the collaborationist administration had been set up with the task of "suppressing the Partisan national-liber-

24 Cf. a brief bibliography of major works: Karsten Linne, Florian Dierl, „Einleitung“, Arbeitskräfte als Kriegsbeute: Der Fall Ost- und Südosteuropa 1939-1945, eds Karsten Linne, Florian Dierl, (Belin: Metropol, 2011), 7-9.

25 The journal in question is not a general historical journal, but a fairly specialized one, so one would expect its editorial bord to be better informed of their field of expertise.

26 We will not dwell on German spelling mistakes such as Stab Generalbevollmactiggten fur Wirtschaft in Serbien in stead of Stab des Generalbevollmächtigten für Wirtschaft in Serbien, although they too should have been the concern if not of the authors, than of the editors of the journal that aspires to prominence in its field. Obradović, Novaković, "Milan Nedic's Quisling Regime", 95.

27 Avramovski, Treći rajh i Borski rudnik, 82.

28 Ibid, 107-130. 
ation movement" and "mobilizing all of Serbia's economic potentials with the aim (sic) of supporting Nazi Germany's war effort." While the second part of the sentence is true, the first one is not since the collaborationist administration in the form of the Council of Commissars, headed by Milan Aćimović, was installed on April 30, 1941, i.e. more than a month before the partisan uprising started. Small wonder that the authors - having declared their ideological colors at the very beginning - read such content into the historical facts.

In keeping with communist historiography, which tended to depict living conditions of ordinary people in even bleaker colors than they actually were, the authors cite on page 93 the prices of basic foodstuffs in mid-1942: again, quoting no source. That is only one side of the problem. The other is the consequence of the above discussed methodological shortcomings. Thus the authors claim a kilogram of flour cost 400 dinars in July of 1942, whereas Schlarp, quoting German documents, gives the prices at 70 dinars in May of 1942 and at 300 dinars in May of 1943 - on the free (i.e. gray) market. ${ }^{29}$ This raises the question of the relevance of the data concerning the prices and wages that the authors quote, and whether they even correspond to the facts. It is similar with the number of Serbian laborers working in Germany during World War II. On page 96 the authors (wrongly citing the page number) refer to a statement that Tanasije Dinić made to the communist investigators after the war, when he claimed that more than 150,000 people had been sent to work in the Reich. ${ }^{30}$ They accept this number uncritically, even though the State Commission for Establishing the Crimes of the Occupiers and their Abettors (whose findings they take for Gospel truth in other places) established that 80,000 people from Serbia had been sent to work to Germany. ${ }^{31}$ On page 98 , the authors quote Barbara Wiesinger, who claims that 161,000 forced laborers were recruited on Serbian territory. They accept this claim too without comment. Had they utilized Schlarp's book, they would have seen that the highest number of laborers from Serbia (voluntary and forced) was $65,743{ }^{32}$ Thus, the number of 161,000 laborers could have been roughly correct only if the POWs, who had also been used for forced labor, had been counted. Unfortunately, the authors pay no attention to such finesses and do not try to establish the truth.

\footnotetext{
29 Schlarp, Wirtschaft und Besatzung, 366.

30 Borković, Kontrarevolucija, II, 64.

31 Nikola Živković, Ratna šteta koju je Nemačka učinila Jugoslaviji u Drugom svetskom ratu, (Beograd: Institut za savremenu istoriju, 1975), 167.

Schlarp, Wirtschaft und Besatzung, 210.
} 
Probably the best example of how little - due to faulty methodology and superficiality - the authors know about their subject matter can be found on page 102. It reads: "The international labor camp Borski Rudnik, was a type of prison set up by the German occupying forces in Serbia during the Second World War for political opponents, members of certain ethnic and religious groups and civilians from Serbia and enslaved Europe..." The Borski Rudnik international labor camp never existed: laborers were held in 33 camps bearing mostly the names of German towns. ${ }^{33}$ The camp the authors probably had in mind was the penal camp near the monument in Bor where political prisoners and fugitives from "mandatory labor" were held. The problem is that the authors did not delve deeper into their subject so the difference between the so-called "mandatory labor" - which was also forced but was performed under somewhat more lenient conditions and was depicted as a civic duty by the collaborationist authorities - and what was officially called "forced labor" and was officially a form of punishment, was lost on them. The fact that the authors were not quite certain what they were writing about is proven by mentioning the TOT Organization camp on page 110 . No doubt, they had in mind the Todt Organization, the very same one they mentioned in the wrong context on page 90. This way, due to the authors' sloppiness, the less knowledgeable reader could presume that TOT is some kind of unexplained acronym..$^{34}$ Just who the Schmiots (sic!) were, who, according to the authors, ran the TOT camp (sic), the present author could not find out in any relevant handbooks on the Third Reich, ${ }^{35}$ or in reference books on characters from classical mythology, or even from the works of J.R.R. Tolkien. ${ }^{36}$

The list of mistakes could go on and on, but since we chose this article only as a spot-check, those already mentioned suffice to show the quality of this paper. As we have said in the beginning, it is not our inten-

33 Živković, Ratna šteta, 173-174.

34 The Todt Organization was named after its founder Fritz Todt (1891-1942).

35 Cf. James Taylor, Warren Shaw, A Dictionary of the Third Reich, (London: Grafton, 1988); Friedman Bedürftig, Drittes Reich und Zweiter Weltkrieg. Das Lexikon, (München, Zürich: Pieper, 2004).

36 Cf. Larousse Encyclopedia of Mythology, (London: Batchworth Press Ltd., 1959); Arthur Cotterell, Die Enyzklopädie der Mithologie, (Reichelsheim: Edition XXL GmgH, 2000); J.R.R. Tolkien Encyclopedia. Scholarship and Critical Assessment, ed. Michael D. C. Drout, (Abington: Taylor and Francis Ltd., 2006); David Day, Tolkien. The Illustrated Encyclopedia, (New York: Touchstone, 1993). A caveat is in place here: the field of mythology and literary genre called fantasy is ever-expanding and lies, in any case, beyond this author's field of expertise, so maybe the Schmiots will be identified by some future researcher. 
tion to dwell on this particular article that does not deserve special attention, but rather to use it in order to point out to the quality of the journal in which it was published and consequently of the Web of Science Core Collection that indexed this article despite its doubtful academic quality. This poses the question of the overall quality of other journals on the lists recommended by the Ministry. This concerns especially those dealing with temporally, geographically, academically, etc. highly diversified humanities; researchers in natural sciences, engineering, and medicine will find it hard to fob off shoddy works since their fields of research share the common sets of knowledge throughout the world. However, we must stress that we do not wish to imply that the lists used by the Ministry are necessarily flawed, but rather to suggest that they be checked for possible "rotten apples."

We believe that the example we have dealt with in this article proves clearly enough that the lists of relevant journals and indices, despite a number of journals and works of undoubtedly good quality on the lists and indexes supported by the Ministry, is in need of constant monitoring and revising. The example we chose to adduce was one of the authors having only a limited knowledge of their subject, publishing their paper in a journal whose editors know even less about the topic of the article they publish, and of a collection indexing it, which seems to know nothing about the quality of either the article, or the journal in question. While remaining part of the world-wide academic networks, it is high time we stop copying foreign models and turn to making our own, i.e. those adapted to our needs and conditions. All our academic disciplines and most researchers are mature enough to be able to come up with lists of relevant journals (Serbian and foreign) in their respective fields. To be sure, this would be a bit harder than just taking over someone's list and supplementing it with a couple of domestic titles, but it would be worth the effort. A better and constantly revised list of relevant journals (that should certainly include foreign journals too!) would be a better guarantee of the quality of the papers published, which in turn would enable a more equitable academic evaluation and financial remuneration. At the same time, those doing the evaluation of academic achievements of our scholars (especially in the humanities) should take foreign lists and indices with more than one grain of salt - as the spot-check in this article has conclusively proved. If our researchers are to be indexed on lists acknowledged in the whole wide world, let it be those who really deserve it. 


\section{Summary}

The paper proposes a reexamination of the validity of the various lists and indexes of scholarly journals supported by the Ministry of Education, Science, and Technological Development of the Republic of Serbia. The author feels that the publication of articles in the journals that feature on these lists could lead to a wrong evaluation, i.e. that publishing in otherwise good, but for our scientific community irrelevant journals, could bring undue points and visibility to certain authors who do not deserve them. The very fact that a journal is on a list can mislead less informed readers, especially foreign, into taking for granted the results of articles published in such journals, spread them around, doing thus a disservice to science. In order to illustrate how dangerous papers of spurious quality featuring on certain lists and indexes can be, the author subjects to well-founded critique an article from his field of expertise. Based on that example, the author pleads once again for caution and against lending credence to quality of certain articles just because they had been published in a journal featuring on a list or an index.

\section{Sources and Literature}

- Aleksić, Dragan. „Prinudni rad u Srbiji u Drugom svetskom ratu“. Logori, zatvori i prisilni rad u Hrvatskoj/Jugoslaviji 1941-1945, 1945-1951, ur. Vladimir Geiger, 133-149. Zagreb: Hrvatski institut za povijest, 2010.

- Aleksić, Dragan. „Problem radne snage u industriji i rudarstvu Srbije u Drugom svetskom ratu“. Tokovi istorije 3-4/1997, 89-110.

- $\quad$ Aleksić, Dragan. Privreda Srbije u Drugom svetskom ratu. Beograd: Institut za noviju istriju Srbije, 2002. (cyrillic)

- Avramovski, Živko. Treći rajh i Borski rudnik. Bor: Muzej rudarstva i metalurgije, 1975.

- Bedürftig, Friedman. Drittes Reich und Zweiter Weltkrieg. Das Lexikon. München, Zürich: Pieper, 2004.

- Borković, Milan. Kontrarevolucija u Srbiji. Kvislinška uprava u Srbiji 19411944, I-II. Beograd: Sloboda, 1979.

- Comparative Fascist Studies. New Perspectives, ed. Constantin Iordachi. London, New York: Taylor and Francis Ltd., 2010.

- $\quad$ Cotterell, Arthur. Die Enyzklopädie der Mithologie. Reichelsheim: Edition XXL $\mathrm{GmbH}, 2000$.

- Day, David. Tolkien. The Illustrated Encyclopedia. New York: Touchstone, 1993.

- Dragosavljević, Vasilije. "Ideološki uticaj evropskog fašizma na JNP Zbor (1934-1940)“. Istorijska tribina mladih saradnika, 93-108. Beograd: Institut za noviju istoriju Srbije, 2013, (cyrillic) 
- Gligorijević, Branislav. „Osobenosti fašizma u Jugoslaviji dvadesetih godina“. Marksistička misao 3/1986, 32-44.

- Gligorijević, Branislav. „Politički pokreti i grupe s nacionalsocijalističkom ideologijom i njihova fuzija u Ljotićevom 'Zboru'“. Istorijski glasnik 4/1965, 35-83.

- $\quad$ Glišić, Venceslav. Teror i zločini nacističke Nemačke u Srbiji 1941-1944. Beograd: Rad, 1970.

- Janjetović, Zoran. Collaboration and Fascism under the Nedić Regime. Belgrade: Institut za noviju istoriju Srbije, 2018.

- Janjetović, Zoran. "Devisen statt Entschädigung. Die Wiedergutsverhandlungen zwischen der Bundesrepublik und Jugoslawien". Die Grenzen der Wiedergutmachung. Die Entschädigung für NS-Verfolgte in West- und Osteuropa 1945-2000, eds Hans Günter Hockerts, Claudia Moisel, Tobias Winstel, 633666. Göttingen: Wallstein Verlag, 2006.

- Janjetović, Zoran. "Dimitrije Ljotić - ein antieuropäischer Europäer unter jugoslawischen Politkern". Attraktionen und Irritationen. Europa und sein Südosten im langen 19. Jahrhundert, ed. Harald Heppner, 179-194. Berlin: Peter Lang, 2019.

- Janjetović,Zoran. „Dimitrije Ljotić and World War II“. Istorija 20. veka 1/2018, 93-118. doi: 10.29362/ist20veka.2018.1.jan.93-118

- Janjetović, Zoran. “The Exploitation of Economy and Manpower in the Territory of Yugoslavia during the Second World War. Historiographical Overview. Results and Pending Research“. Südost-Forschungen 77/2018, 253269. doi: 10.1515 /sofo-2018-770116

- Janjetović, Zoran. „U skladu sa nastalom potrebom“... Prinudni rad u okupiranoj Srbiji 1941-1944. Beograd: Institut za noviju istoriju Srbije, 2012.

- Jovanović, Žarko S. Neostvareni ratni ciljevi Draže Mihailovića u Srviji 19411945. Beograd: Institut za noviju istoriju Srbije, 2001 (cyrillic)

- J.R.R. Tolkien Encyclopedia. Scholarship and Critical Assessment, ed. Michael D. C. Drout. Abington: Taylor and Francis Ltd, 2006.

- $\quad$ Kuljić, Todor. Fašizam. Socioliško-istorijska studija. Beograd: Nolit, $1987^{2}$.

- Lacko, Mikloš. „Fašizam u istočnoj i srednjoj Evropi. Prilog opštoj definiciji fašizma“. Marksistička misao 3/1986, 120-135.

- $\quad$ Larousse Encyclopedia of Mythology. London: Batchworth Press Ltd, 1959.

- $\quad$ Linne, Karsten, Florian Dierl. "Einleitung“. Arbeitskräfte als Kriegsbeute: Der Fall Ost- und Südosteuropa 1939-1945, eds Karsten Linne, Dierl, Florian, 7-14. Berlin: Metropol, 2011.

- Manošek, Valter. Holokaust u Srbiji. Vojna okupaciona politika i uništavanje Jevreja 1941-1942. Beograd: Službeni list, 2007.

- Obradović, Marija, Nada Novaković. “Milan Nedic’s Quisling Regime and Forced Labor in Serbia from 1941 to 1944". E-Journal of International and Comparative Labor Studies 3, 2019, 85-113. 
- $\quad$ Payne, Stanley G. A History of Fascism 1914-1945. London, New York: Rutledge, 2003.

- $\quad$ Schlarp, Karl-Heinz. Wirtschaft und Besatzung in Serbien 1941-1944. Ein Beitrag zur nationalsozialistischen Wirtschaftspolitik in Südosteuropa. Stuttgart: Franz Steiner Verlag, 1986.

- $\quad$ Shepherd, Ben. Terror in the Balkans. German Armies and Partisan Warfare. Harvard: Harvard University Press, 2012.

- $\quad$ Taylor, James, Warren Shaw. A Dictionary of the Third Reich. London: Grafton, 1988.

- Van Dartel, Geert. "Nationalities and Religion in Yugoslavia”. Yearbook of European Studies 5/1992, 23-46.

- Velimirović, Nikolaj. Nacionalizam svetog Save. Beograd: Mala narodna biblioteka, 1994. (cyrillic)

- Who Were the Fascists. Social Roots of European Fascism, eds Stein Ugelvik Larsen, Bernt Hagtvet, Jan Petter Myklebust. Bergen, Oslo, Tromsø: Universitetsforlaget, 1980.

- Zundhausen, Holm. Istorija Srbije od 19. do 21. veka. Beograd: Clio, 2008. (cyrillic)

- $\quad$ Žerjavić, Vladimir. Population Loses in Yugoslavia 1941-1945. Zagreb: Dom i svijet, 1997.

- $\quad$ Živković, Nikola. Ratna šteta koju je Nemačka učinila Jugoslaviji u Drugom svetskom ratu. Beograd: Institut za savremenu istoriju, 1975. 


\title{
Резиме
}

Зоран Јањетовић

\section{О листама, индексима и квалитету: да ли су повезани?}

\begin{abstract}
АпстРАКт: Полазећи од аргументоване критике једног од радова са Web of Science Core Collection, чланак преиспитује да ли постоји веза између квалитета радова, часописа у којима се објављују, спискова на којима се часописи налазе и индекса који бележе те радове, правећи често неоправдану рекламу ауторима који то не заслужују. Аутор се бави лошим последицама такве кратковиде праксе и залаже се за сталну ревизију листа и индекса које уважава Министарство просвете, науке и технолошког развоја Републике Србије, да би се повећала њихова релевантност као мерила академских постигнућа.

КљУчНЕ РЕчи: часописи, листе, индекси, методологија, принудни рад
\end{abstract}

У овом раду аутор предлаже преиспитивање ваљаности листа и индекса научних часописа које подржава Министарство просвете, науке и технолошког развоја Републике Србије. Полази од тога да објављивање радова у часописима са поменутих листи може да заведе на погрешно вредновање, тј. да објављивање у добрим, али за потребе наше науке некомпетентним часописима, појединим истраживачима може донети незаслужене бодове или уочљивост. Сама чињеница да је часопис на некој листи или индексу може да завара мање стручне, посебно иностране читаоце, да резултате радова објављених у таквим часоисима некритички прихватају и даље шире, чинећи тако медвеђу услугу науци. Ради илустрације опасности које носе поједини радови непровереног квалитета на одређеним листама и индексима, аутор подвргава добро утемељеној критици један чланак из поља своје стручности. На основу тог примера још једном пледира за опрез при поклањању поверења квалитету чланака само на основу тога што су објављени у часопису који је на некој листи или индексу. 